\title{
NEW EU APPROACH IN COMBATING CRIMINAL OFFENCES AFFECTING FINANCIAL INTERESTS
}

\author{
Nikola Paunović, PhD Candidate, Teaching and Research Assistant \\ Faculty of Law, University of Belgrade \\ Bulevar kralja Aleksandra, 67, Belgrade \\ dzoni925@gmail.com
}

\begin{abstract}
Financial crimes represent a significant problem at the EU level since they are damaging the integrity of the financial sector. In that context, it should be noted that there is a range of offences concerning financial crimes, so it became undisputed that such criminal activities should be prescribed in a comprehensive manner at the EU level. In that regard, it is worthwhile noting that Directive (EU) 2017/1371 on the fight against fraud to the EU's financial interests by means of criminal law establishes the definition of criminal offences concerning combating fraud and other illegal activities affecting the EU's financial interests. This is the reason why the first part of the paper is dedicated to the analysis of the criminal offences affecting the EU's financial interests. However, the prescribed list of financial crime in Directive (EU) 2017/1371 represented only required but not the sufficient step for combating this type of criminal activities since there was a lack of legal possibilities for national and European authorities to access to relevant financial information as well as the lack of cooperation between them. On these grounds, the Directive (EU) 2019/1153 laying down rules facilitating the use of financial and other information for the prevention, detection, investigation or prosecution of certain criminal offences was adopted on 20 June 2019. For that reason, the second part of the article deals with the legal measures referred to in Directive (EU) 2019/1153 concerning the possibilities for the access by competent authorities to financial information as well as the conditions for the exchange of information between competent authorities and financial intelligence units as well as between financial intelligence units and Europol. Furthermore, since the protection of the financial interests by means of criminal law, cannot be sufficiently achieved only with individual measures adopted by Member States, it seems compulsory to take into consideration significant improvements achieved in this area at international level in order to examine whether the new EU framework is in compliance with existing international standards. Finally, since the Republic of Serbia has, in the context of accession and negotiations process to EU, recently amended the framework concerning criminal offences with regard to combatting fraud and other illegal activities affecting the financial interests, the third part of the paper is dedicated to the analysis of the national framework in order to examine its compliance with EU framework. In concluding remarks, it is noted that although in the recent
\end{abstract}


period there have been significant improvements in the framework on the protection of the EU financial interests against financial crimes there is still a lack of effective implementation of adopted standards. Bearing in mind the above, some recommendations for accelerating the implementation of adopted measures are listed.

Keywords: financial interests, criminal offences, criminal law, Directive (EU) 2017/1371, Directive (EU) 2019/1153

\section{INTRODUCTION}

In recent years, emerging new phenomenological forms have brought to light in the respect of criminal offenses affecting the EU's financial interests, in particular regarding the way how criminals conduct their operations. Methods and techniques for acquiring funds from the EU budget and then using them for committing fraud and other criminal offenses affecting the EU's financial interests have become very sophisticated, often unnoticeable and difficult to detect, making hardly possible the tracking of money flows. As their fund-raising activities were substantially increased, in order to enlarge their profits, criminals were encouraged to evolve new ways of conducting their activities by creating organized criminal networks, which enabled them to engage in large criminal operations. Consequently, due to the fact that detection, prevention and investigation of criminal offenses affecting the EU's financial interests was faced with an increase of number of difficulties regarding gathering of evidence as well as because the proving of this type of crime was significantly hampered at the EU level, it was required to create, develop and adopt new legal measures regarding the fight against fraud and other offenses causing negative effects for the EU's financial activities. In this regard, it was obvious that the protection of EU's financial interest against illegal activities should be improved by means of criminal law. For that reason, at the EU level, already in 2012, the proposal of the new Directive on the fight against fraud and other crimes affecting the EU's financial interests by means of criminal law was submitted. After the completion of internal procedure, in 2017, Directive (EU) $2017 / 1371$ on the fight against fraud to the EU's financial interests by means of criminal law was finally adopted (hereinafter: Directive (EU) 2017/1371). ${ }^{1}$ By adopting the Directive (EU) 2017/1371, the EU legal framework was covered by the substantive issues in the respect of the definitions of criminal offences concerning combating fraud and other illegal activities affecting the EU's financial

Directive (EU) 2017/1371 of the European Parliament and of the Council of 5 July 2017 on the fight against fraud to the Union's financial interests by means of criminal law, Official Journal of the European Union, L 198/29 of 28 July 2017. Juszczak, A., Sason, E., The Directive on the Fight against Fraud to the Union's Financial Interests by means of Criminal Law (PFI Directive), [https://eucrim.eu/articles/ the-pfi-directive-fight-against-fraud/] Accessed on 15. April 2020 
interests. ${ }^{2}$ However, adopting of this Directive was only the required step, but not sufficient, in the respect of the protection of EU's financial interests against illegal criminal activities, since the procedural matters, including the modality of the exchange of required financial information relevant for detection, prevention and investigation of fraud and other financial crimes, had not been agreed. In this sense, a significant step forward has represented the adoption of new Directive (EU) 2019/1153 laying down rules facilitating the use of financial and other information for the prevention, detection, investigation or prosecution of certain criminal offences (hereinafter: Directive (EU) 2019/1153) adopted in 2019.3 From this perspective, in this paper firstly, it will be analyzed and discussed new EU framework concerning the nexus between the fight against fraud to the EU's financial interests by means of criminal law and the facilitating the access, use and dissemination of financial and other information for the prevention, detection, investigation or prosecution of fraud and other financial crimes. Furthermore, the focus will be on the international standards of the importance in this area, especially those made by the Financial Action Task Force. Finally, the relevant framework of the Republic of Serbia will be considered.

\section{THE EU APPROACH CONCERNING COMBATING FRAUD AND OTHER ILLEGAL ACTIVITIES AFFECTING THE FINANCIAL INTERESTS BY MEANS OF CRIMINAL LAW}

In the line with Article 2 of Directive (EU) 2017/1371 the term of EU's financial interests is related to all revenues, expenditure and assets covered by as well as acquired through the EU budget or the budgets of the EU institutions, bodies and offices. For that reason, this Directive was adopted with the purpose to provide minimum rules regarding recognition of and fight against criminal offences affecting the EU's financial interest. In this sense, it should be noted that the Directive (EU) 2017/1371 makes the difference between two types of conduct which can negatively affect and threaten to EU's financial interests. On the one side, this Directive deals with the fraud, while on the other side, it approaches to

Kostić, J., Krivičnopravna zaštita finansijskih interesa Evropske unije, Institut za uporedno pravo, Beograd, 2018, pp. 44-48

3 Directive (EU) 2019/1153 of the European Parliament and of the Council of 20 June 2019 laying down rules facilitating the use of financial and other information for the prevention, detection, investigation or prosecution of certain criminal offences, Official Journal of the European Union, L 186/122 of 11 July 2019. 2.Wahl, T., New Directive on Law Enforcement Access to Financial Information, [https:// eucrim.eu/news/new-directive-law-enforcement-access-financial-information/], accessed on 15. April 2020 
the consideration of other criminal offences affecting the EU's financial interests. ${ }^{4}$ To start with the fraud as the special type of conduct which adversely affect the EU's financial interests.

\subsection{FRAUD AFFECTING THE EU'S FINANCIAL INTERESTS}

Since the fraud affecting the EU's financial interests is usually perpetuated by organized criminal networks, causing that this crime is not limited to a single country, Directive (EU) 2017/1371 pursuant to Article 3 obliges all Member States to ensure that this crime constitutes a criminal offence at the EU level when it is committed intentionally. ${ }^{5}$ By contributing to the suppression of the fraud affecting the EU's financial interests, Directive (EU) 2017/1371 has recognized four types of this crime, in the area of: 1) non-procurement-related expenditure; 2) procurement-related expenditure; 3) revenue arising from VAT own resources and 4) revenue other than revenue arising from VAT own resources. ${ }^{6}$ In order to be consider as illegal last two types of this crime should be committed as the part of the cross-border fraudulent schemes.

First of all, when it comes to non-procurement-related expenditure, Directive (EU) 2017/1371 makes the difference between three possible modality of committing the fraud in the area, by prescribing: a) the use or presentation of false, incorrect or incomplete statements or documents; b) non-disclosure of information in violation of a specific obligation and c) the misapplication of such funds or assets. However, it should be noticed that the mere fact of executing the abovementioned acts of execution is not sufficient for the existence of this crime. In other words, another element is required to become such conduct illegal. Thus, in the respect of the use or presentation of false, incorrect or incomplete statements or documents as well as non-disclosure of information in violation of a specific obligation, the required element is the consequence of the exercised act. Namely, the committing of these two acts should have as its effect the misappropriation or wrongful retention of funds or assets from the EU budget or budgets managed by the EU, or on its behalf. On the other side, in the regard of the third act of execution, the required element is the specific purpose of committing the fraud.

Picard, M, Financial Crimes: The constant challenge of seeking effective prevention solutions, Journal of Financial Crime, vol.15, no.4, 2008, p. 386

5 Mathis, A., Combating Fraud and Protecting the EU's Financial Interests, European Parliament, Brussels, 2020, p. 5

6 Šuput, J., Harmonizacija nacionalnog zakonodavstva Republike Srbije sa Konvencijom o zaštiti finansijskih interesa Evropske unije, Evropsko zakonodavstvo, vol.13 no. 47/48, 2014, p. 192 
Precisely, the misapplication of the EU's funds or assets should be undertaken for purposes other than those for which they were originally granted. ${ }^{7}$

Moreover, in the context of the second type of this crime concerning procurement-related expenditure, it should be pointed out that Directive (EU) 2017/1371 is recognized the same phenomenological forms of execution with the same special elements required for the existence of the fraud in the given case, as it the situation with the non-procurement-related expenditure. Therefore, it is about the following acts or omissions relating to: a) the use or presentation of false, incorrect or incomplete statements or documents, which has as its effect the misappropriation or wrongful retention of funds or assets from the EU budget or budgets managed by the EU, or on its behalf; b) non-disclosure of information in violation of a specific obligation, with the same effect; or c) the misapplication of such funds or assets for purposes other than those for which they were originally granted, which damages the EU's financial interests. However, it is noteworthy that in respect of procurement-related expenditure it is prescribed one more element required in order to such conduct be considered as the fraud. What is meant here is the element of the intention specified in Directive (EU) 2017/1371 for the procurement-related expenditure, but not also for non-procurement-related expenditure. Thus, the procurement-related expenditure as the special form of the fraud should be considered as such only if it is committed in order to make an unlawful gain for the perpetrator or another by causing a loss to the EU's financial interests.

Furthermore, the next phenomenological form of execution of the fraud is related to the area of revenue arising from value added taxes (hereinafter: VAT) own resources. ${ }^{8}$ In this regard, three types of illegal acts are prescribed in relation to: a) the use or presentation of false, incorrect or incomplete VAT-related statements or documents; b) non-disclosure of VAT-related information in violation of a specific obligation; c) the presentation of correct VAT-related statements. ${ }^{9}$ However, it should be noticed that the mere fact of executing the abovementioned acts of execution is not sufficient for this existence of this crime, since the existence of others elements is required in order to be treated such conduct as the fraud. Therefore, in the respect of the use or presentation of false, incorrect or incomplete VAT-related statements or documents and non-disclosure of VAT-related information in vio-

Sánchez D., (a) The Directive on the Fight against Fraud to the Union's Financial Interests and its Transposition into the Spanish Law, Perspectives on Federalism, vol. 11, no. 3, 2019, p. 128

8 OECD, Improving Co-operation between Tax Authorities and Anti-Corruption Authorities in Combating Tax Crime and Corruption, OECD, Paris, 2018, pp. 21-33

9 Maesa, C., Directive (EU) 2017/1371 on the Fight Against Fraud to the Union's Financial Interests by Means of Criminal Law: A Missed Goal?, European papers: a journal on law and integration, vol. 3, no. 3, 2018, p. 1461-1462 
lation of a specific obligation as well, the additional elements is the consequence. Precisely, the committing of these two acts should have as an effect the diminution of the resources of the EU budget. Diversely, for the third phenomenological form of execution of the fraud the required element is the specific purpose of committing this crime meaning that the presentation of correct VAT-related statements should be undertaken for the purposes of fraudulently disguising the non-payment or wrongful creation of rights to VAT refunds. ${ }^{10}$

Finally, regarding the fourth phenomenological form of execution of the fraud, it should be recalled that is related to revenue other than revenue arising from VAT own resources. In this sense, three ways of execution are prescribed in relation to: a) the use or presentation of false, incorrect or incomplete statements or documents; b) non-disclosure of information in violation of a specific obligation and c) misapplication of a legally obtained benefit. As it was the case with the previous illegal forms, also in this regard the mere fact of executing the abovementioned acts of execution is not sufficient for this existence of this crime, since the existence of others elements is required in order to be treated such conduct as the fraud. Nevertheless, in this case for all three ways of execution are prescribed the same special element which is referred to the special consequence, required for the existence of the crime. So, the committing of these acts should have as its effect the illegal diminution of the resources of the EU budget or budgets managed by the EU, or on its behalf.

\subsection{OTHER CRIMINAL OFFENCES AFFECTING THE EU'S FINANCIAL INTERESTS}

By protecting EU's financial interests from other criminal offences, Directive (EU) 2017/1371 in consonance with Article 4 deals with three types of criminal behavior including: 1) money laundering; 2) passive and active corruption and 3) misappropriation. The essential element of money laundering is prescribed by Directive (EU) 2015/849 of 20 May 2015 on the prevention of the use of the financial system for the purposes of money laundering or terrorist financing ${ }^{11}$, while the elements of other two abovementioned criminal offenses are contained in Directive (EU) 2017/1371. According to Article 1 of Directive (EU) 2015/849, terrorist

10 Tudor, G., Criminalizing fraud affecting the European Union's financial interests by diminution of VAT resources, Juridical Tribune, vol. 9, no. 1, 2019, p.142

11 Directive (EU) 2015/849 of the European Parliament and of the Council of 20 May 2015 on the prevention of the use of the financial system for the purposes of money laundering or terrorist financing, Official Journal of the European Union, L 141/73 of 05 June 2015, (hereinafter: Directive (EU) 2015/849) 
financing means the provision or collection of funds, by any means, directly or indirectly, with the intention that they be used or in the knowledge that they are to be used, in full or in part, in order to carry out any of terrorist offences. ${ }^{12}$ On the other hand, it is worthwhile mentioning that in the context of money laundering there are four types of conduct, which when committed intentionally, shall be regarded as this crime. ${ }^{13}$ The first type of conduct covered by this Directive includes the acts of the conversion or transfer of property. In order to be considered illegal such conduct must include the elements of specific knowledge and specific purpose of committing this crime. Namely, this act of execution should be conducted with the knowledge that such property is derived from criminal activity or from an act of participation in such activity and for the purpose of concealing or disguising the illicit origin of the property or of assisting any person who is involved in the commission of such an activity to evade the legal consequences of that person's action. Furthermore, the second type of conduct covers situations of concealment or disguise of the true nature, source, location, disposition, movement, rights with respect to, or ownership of, property. Also, in this case the additional element is required regarding the specific knowledge. In this sense, the perpetuator should act knowing that such property is derived from criminal activity or from an act of participation in such an activity. Finally, the next type of conduct is related to acts of the acquisition, possession or use of property. ${ }^{14}$ The additional element in respect of knowledge is applicable also to this situation, but with the difference that such knowledge of perpetuator should exist at the time of receipt of property deriving from criminal activity or from an act of participation in such an activity. Finally, last type of conduct covers different situations such as participation in, association to commit, attempts to commit and aiding, abetting, facilitating and counselling the commission of any of the abovementioned actions. ${ }^{15}$ The analyzed essential elements required for the consideration of an act of money laundering as such, in accordance with Directive (EU) 2015/849, however, are not sufficient for the purpose of Directive (EU) 2017/1371. In other words, in order to be regarded one conduct as money laundering, except this elements prescribed by Directive (EU) 2015/849, in the respect of Directive (EU) 2017/1371, it is required that

12 Finn, H., The fifth anti-money laundering and terrorist financing directive (AML 5)-Key aspects and changes, Arendt \& Medernach, Luxembourg, 2018, p. 1

13 Tomić S., New EU Directive On The Prevention Of The Use Of The Financial System For The Purposes Of Money Laundering And Terrorist Financing, Bankarstvo, vol. 47, no. 2, 2018, pp. 108-113

14 Paunović, N., Terrorist Financing As The Associated Predicate Offence Of Money Laundering In The Context Of The New EU Criminal Law Framework For The Protection Of The Financial System, Duić, D.; Petrašević, T.; Novokmet, A. (eds.), EU and Member States - Legal and Economic Issues, Faculty of Law, Josip Juraj Strossmayer University of Osijek, Osijek, 2019, p. 662

15 Fletzberger, B., 5th Anti-Money Laundering Directive - a summary of the main points, PayTechLaw, 2018, p. 1 
property derived from money laundering is acquired by some of offenses covered by this Directive. ${ }^{16}$

On the other side, in accordance with Article 4 paragraph 2, regarding corruption as the form of other criminal offences affecting EU's financial interests, it is noteworthy that Directive (EU) 2017/1371 makes the difference between passive and active form of this crime. ${ }^{17}$ In that sense passive corruption means the action of a public official who, directly or through an intermediary, requests or receives advantages of any kind, for himself or for a third party, or accepts a promise of such an advantage, to act or to refrain from acting in accordance with his duty or in the exercise of his functions in a way which damages or is likely to damage the EU's financial interests. On the other hand, active corruption means the action of a person who promises, offers or gives, directly or through an intermediary, an advantage of any kind to a public official for himself or for a third party for him to act or to refrain from acting in accordance with his duty or in the exercise of his functions in a way which damages or is likely to damage the EU's financial interests. Ultimately, as reported by Article 4 paragraph 3, Directive (EU) 2017/1371 deals with the misappropriation as the form of other criminal offences affecting EU's financial interests. According to this Directive, misappropriation means the action of a public official who is directly or indirectly entrusted with the management of funds or assets to commit or disburse funds or appropriate or use assets contrary to the purpose for which they were intended in any way which damages the EU's financial interests. ${ }^{18}$

As we can notice, the common element in the respect of all three crimes abovementioned is that the perpetuator or passive subject can be public official. For that reason, it was required to define who should be considered as public official. In this regard, in Article 4 paragraph 4 Directive (EU) 2017/1371 defines two categories of person which shall be regarded as public official. Thus, the public officer is not only EU official or a national official, including any national official of another Member State and any national official of a third country, but also any other person assigned and exercising a public service function involving the management of or decisions concerning the EU's financial interests in Member States or third countries. Bearing in mind that the terms of EU official and a national official, include a lot of different types of official, it was supposed to precise the

16 Savona, E.; Riccardi, M., Assessing the risk of money laundering: research challenges and implications for practitioners, European Journal on Criminal Policy and Research, 2019, vol. 25, no. 1, pp. 1-4

17 Fight Against Corruption, [https://ec.europa.eu/info/sites/info/files/file_import/european-semester_ thematic-factsheet_fight-against-corruption_en_0.pdf], p. 2, accessed on 15. April 2020

18 Sánchez, D., (b), The European Union Criminal Policy against Corruption: Two Decades of Efforts, Politica Criminal, vol 14, no. 27, 2019, p. 531 
meaning of these notions. Thus, it is specified that under the term of EU official it is meant not only a person who is: an official or other servant engaged under contract by the EU within the meaning of so called Staff Regulations, but also a person who is seconded to the EU by a Member State or by any public or private body, who carries out functions equivalent to those performed by EU officials or other servants. On the other side, it is determined that the term of national offcial shall be understood by reference to the definition of official or public official in the national law of the Member State or third country in which the person in question carries out his or her functions. Although, at the first glance, it appears that the notion of national official is prescribed in a general manner and without any specific details and criteria regarding how Member States should define this notion, it is not the case, since Directive (EU) 2017/1371 provides additional elements specifying who should be understood as the national official. Thus, the term national official shall include any person holding a legislative, an executive, administrative or judicial office at national, regional or local level. However, this is only a tentative, non-binding definition, since in the case of proceedings involving a national official of a Member State, or a national official of a third country, initiated by another Member State, the latter shall not be bound to apply the definition of national official, except insofar as that definition is compatible with its national law.

\section{NEW EU LEGAL MEASURES CONCERNING THE POSSIBILITIES FOR THE ACCESS TO FINANCIAL INFORMATION OR TO OTHER INFORMATION AND THE EXCHANGE OF INFORMATION}

Since the prevention, detection, investigation or prosecution of abovementioned serious criminal offences affecting EU's financial interest is not enough effective without special legal measures for the access to and the use of financial information and bank account information by competent authorities, and consequently for the exchange of such information, it the following lines it will be analyzed the new EU legal approach in this area. In the context of the special rule concerning the access to relevant information, it should be cleared that Directive (EU) 2019/1153 pursuant to Article 2 makes a difference between three types of information including: 1) financial information; 2) law enforcement information and 3) bank account information. In the respect of the financial information it is important to note that it means any type of information or data, such as data on financial assets, movements of funds or financial business relationships, which is already held by Financial Intelligence Unit (hereinafter:FIUs) to prevent, detect and effectively combat serious crimes such as money laundering and terrorist fi- 
nancing. On the other side, law enforcement information such as criminal records or information on investigations, means both any type of information or data which is already held by competent authorities in the context of preventing, detecting, investigating or prosecuting criminal offences and that information which is held by public authorities or by private entities but which is available to competent authorities without taking of coercive measures under national law. Finally, bank account information means information on bank and payment accounts and safe-deposit boxes contained in the centralized bank account registries.

\subsection{ACCESS BY COMPETENT AUTHORITIES TO BANK ACCOUNT INFORMATION}

By dealing with the issue of access by competent authorities to bank account information, Directive (EU) 2019/1153 covers three topics such as: 1) the access to and searches of bank account information by competent authorities (Article 4); 2) conditions for access and for searches by competent authorities (Article 5) and 3) monitoring access and searches by competent authorities (Article 6). ${ }^{19}$

Generally speaking, the power of competent national authorities to access to and search of, directly and immediately, bank account information is limited to the case when it is necessary for the performance of their tasks for the purposes of preventing, detecting, investigating or prosecuting a serious criminal offence or supporting a criminal investigation concerning a serious criminal offence, including the identification, tracing and freezing of the assets related to such investigation. Access and searches shall be considered to be direct and immediate, inter alia, including the situation where the national authorities operating the central bank account registries transmit the bank account information expeditiously by an automated mechanism to competent authorities, providing that no intermediary institution is able to interfere with the requested data or the information to be provided. However, Directive (EU) 2019/1153 specifies the additional elements required for the legal access. In this sense, access to and searches of bank account information shall be performed only on a case-by-case basis by the staff of each competent authority that have been specifically designated and authorized to perform those tasks. The staff of the designated competent authorities should maintain high professional standards of confidentiality and data protection, while at the same time should be appropriately skilled with technical and organizational measures for the security of the data. Finally, in the context of the protection of bank account information it is worthwhile mentioning that Directive (EU) 2019/1153

19 EU directive gives greater access to financial information, [https://www.taxjournal.com/articles/eu-directive-gives-greater-access-to-financial-information], accessed 15. April 2020 
deals with the issue of monitoring access and searches by competent authorities, prescribing that the authorities operating the centralized bank account registries should ensure that logs are kept each time designated competent authorities access and search bank account information. Furthermore, for the safety reasons, the data protection officers for the centralized bank account registries shall check the logs regularly, and make them available, on request, to the competent supervisory authority. In order to be protected against illegal uses and unauthorized access the logs shall be used only for data protection monitoring, including checking the admissibility of a request and the lawfulness of data processing, and for ensuring data security. Therefore, they shall be erased five years after their creation, unless they are required for monitoring procedures that are ongoing.

\subsection{EXCHANGE OF INFORMATION BETWEEN COMPETENT AUTHORITIES AND FIUS, AND BETWEEN FIUS}

Approaching to the consideration of exchange of information, Directive (EU) 2019/1153 recognizes four types of requests including the following: 1) requests for information by competent authorities to an FIU (Article 7); 2) requests of information by an FIU to competent authorities (Article 8); 3) requests for the exchange of information between FIUs of different Member States (Article 9) and 4) requests for the exchange of information between competent authorities of different Member States (Article 10). ${ }^{20}$

In the respect of the requests for information by competent authorities to an FIU, it is important to stress that each FIU at the EU level is required to cooperate with its designated competent authorities in order to be able to reply, in a timely manner, to reasoned requests for financial information or financial analysis under the following two conditions. ${ }^{21}$ One the one side, it is necessary that financial information or financial analysis is requested on a case-by-case basis, while, on the other side the request should be motivated by concerns relating to the prevention, detection, investigation or prosecution of serious criminal offences. This is important to stress out because any use for purposes beyond those originally approved shall be made subject to the prior consent of that FIU, which shall appropriately explain why refused to reply to a request. Therefore, in the following situations, if these conditions are not fulfilled the FIU shall be under no obligation to comply with the request for information: 1) if there are objective grounds for assuming

\footnotetext{
20 Wahl, T., Commission: Need for Reinforced FIU Cooperation, [https://eucrim.eu/news/commission-need-reinforced-fiu-cooperation/], accessed 15. April 2020

21 Nunzi, A., Exchange of Information and Intelligence among Law Enforcement Authorities a European Union Perspective, Revue internationale de droit penal, vol. 78, no. 1-2, 2007, pp. 143-151
} 
that the request for such information would have a negative impact on ongoing investigations or analyses, or 2) in exceptional circumstances, if disclosure of the information would be clearly disproportionate to the legitimate interests of a natural or legal person or 3) if disclosure of the information would be irrelevant with regard to the purposes for which it has been requested. Finally, in this regards, it should be noted that the designated competent authorities may process the financial information and financial analysis received from the FIU for the specific purposes of preventing, detecting, investigating or prosecuting serious criminal offences other than the purposes for which personal data are collected. This option is in accordance with Article 4 paragraph 2 of Directive (EU) 2016/680 and because of that, it should be permitted in so far as: 1) the controller is authorized to process such personal data for such a purpose and 2) processing is necessary and proportionate to the purpose of preventing, detecting, investigating or prosecuting serious criminal offences. ${ }^{22}$ Reversely, Directive (EU) 2019/1153 includes the situations where requests of information is made by an FIU to competent authorities, obliging its designated competent authorities to reply in a timely manner to requests for law enforcement information made by the national FIU on a caseby- case basis, where the information is necessary for the prevention, detection and combating of money laundering, associate predicate offences and terrorist financing.

Furthermore, Directive (EU) 2019/1153 covers situations which include the exchange of information between FIUs of different Member States. The exchange of information in this sense it possible under three conditions: 1) the exchange of financial information or financial analysis should be relevant for the processing or analysis of information related to serious criminal offenses; 2 ) in the given case it should be about exceptional and urgent circumstances which requires the exchanges of information among FIU's, and 3) FIUs should exchange such information promptly. Finally, Directive (EU) 2019/1153 regulates the situation including exchange of information between competent authorities of different Member States. The exchange of information obtained from the FIU of their Member State between competent authorities is applicable under the following conditions: 1) upon request and on a case-by-case basis and 2) if the financial information or financial analysis is necessary for the prevention, detection and combating of serious criminal offenses. In this regard, it should be emphasized that designated

22 Directive (EU) 2016/680 of the European Parliament and of the Council of 27 April 2016 on the protection of natural persons with regard to the processing of personal data by competent authorities for the purposes of the prevention, investigation, detection or prosecution of criminal offences or the execution of criminal penalties, and on the free movement of such data, Official Journal of the European Union, L 119/89 of 04 May 2016 
competent authorities may use the obtained financial information or financial analysis only for the purpose for which it was sought or provided, since any other use of that information for purposes other than those originally approved is made subject to the prior consent of the FIU providing the information. ${ }^{23}$

\subsection{EXCHANGE OF INFORMATION WITH EUROPOL}

By regulating the issue considering the exchange of information with Europol, Directive (EU) 2019/1153 in accordance with Article 11 and 12 makes a difference between two situations including: 1) the exchange of bank account information to Europol and 2) the exchange of information between Europol and FIUs. In the respect of first situation it may be noted that competent authorities are entitled to reply, through the Europol national unit or by direct contacts with Europol, to duly justified requests made by Europol related to bank account information on a case-by-case basis. Ultimately, under the same conditions each FIU, in the context of the exchange of information between Europol and FIUs, is entitled to reply to duly justified requests made by Europol.

\section{INTERNATIONAL STANDARDS FOR THE PROTECTION OF FINANCIAL SYSTEM BY MEANS OF CRIMINAL LAW}

Bearing in mind the fact that the protection of the financial system by means of criminal law through the prevention, detection and investigation of fraud and other criminal offences targeting financial interests, cannot be sufficiently achieved only by the Member States with individual measures adopted by them, it will be also taken into consideration significant improvements achieved in this area at international level, especially those made by Financial Action Task Force (hereinafter: FATF). ${ }^{24}$ When it comes to the issue of the exchange of information relevant for the protection of the financial system against fraud and other criminal offences targeting financial interests it should be noted that FATF recognizes four types of exchange applicable to specific forms of international cooperation including the following: 1) the exchange of information between FIUs; 2) the exchange of information between competent authorities; 3) the exchange of information between law enforcement authorities and 4) the exchange of information

23 Quintel, T., Follow the Money, if you can Possible solutions for enhanced FIU cooperation under improved data protection rules, Law Working Paper Series Paper, vol. 1, 2019, pp. 6-8

24 Schott, P., Reference Guide to Anti-Money Laundering and Combating the Financing of Terrorism, The World Bank and The International Monetary Fund, Washington DC, 2006, p.128; See also Borlini L., Montanaro, F., The Evolution Of The EU Law Against Criminal Finance: The "Hardening" Of FATF Standards Within The EU George Town Journal Of International Law, vol. 48, 2017, p. 1011 
between non-counterparts. ${ }^{25}$ Generally speaking, this four types of exchange it should be divided into two broader groups, covering on the one side exchange of information between counterparts, and on the other side exchange of information between non-counterparts.

However, before further analyze of this issue, it seem compulsory to make a short consideration of principles applicable to all forms of international cooperation. First of all, it should be mentioned that when making requests for cooperation, authorities which take part in the exchange of information should make their best efforts to enable a timely and efficient execution of the request, as well as the foreseen use of the information requested. Upon request, requesting authorities should provide feedback to the requested competent authority on the use and usefulness of the information obtained. Furthermore, authorities should not place unreasonable or unduly restrictive conditions in the context of the exchange of information, by refusing a request for assistance for example on the grounds that laws require financial institutions to maintain secrecy or confidentiality. Moreover, it should be underlined that exchanged information should be used only for the purpose for which the information was sought or provided. Otherwise, any dissemination of the information to other authorities or third parties, or any use of this information for administrative, investigative, prosecutorial or judicial purposes, beyond those originally approved, should be subject to prior authorization by the requested authority. At a minimum, authorities should maintain appropriate confidentiality for any request for cooperation and the information exchanged, protecting the integrity of the exchanged information in the same manner as they would protect similar information received from domestic sources. In order to fulfill this duty, it should be established controls and safeguards to ensure that information exchanged by authorities is used only in the manner authorized. For that reason, requested authorities may, as appropriate, refuse to provide information if the requesting competent cannot protect the information effectively. These general principles should be applicable to all forms of exchange of information between counterparts or non-counterparts. ${ }^{26}$ To start with the exchange of information between FIUs.

\footnotetext{
25 FATF Recommendation Interpretive Note to Recommendation 40 (Other Forms Of International Cooperation) See in FATF (2012-2019), International Standards on Combating Money Laundering and the Financing of Terrorism \& Proliferation, FATF, Paris, 2019, pp. 108-110

26 FATF (a), ibid., pp. 107-108
} 


\subsection{THE EXCHANGE OF INFORMATION BETWEEN FIUS}

In the respect with the exchange of information between FIUs, it should be emphasized that when requesting cooperation, FIUs should make their best efforts to provide complete factual, and, as appropriate, legal information, including the description of the case being analyzed and the potential link to the requested country. Upon request and whenever possible, FIUs should provide feedback to their foreign counterparts on the use of the information provided, as well as on the outcome of the analysis conducted, based on the information provided. In this regard, it is important to note that FIUs should have the power to exchange two types of information: a) all information required to be accessible or obtainable directly or indirectly by the FIU and b) any other information which they have the power to obtain or access, directly or indirectly, at the domestic level, subject to the principle of reciprocity. ${ }^{27}$ The FATF fulfills its tasks through three roles including: 1) receipt of the information; 2) analysis of the information and 3) dissemination of the information.

In the context of the first mentioned role of FATF, it should be noted that the FIU serves as the central agency for the receipt of information by reporting entities, which at a minimum should contain suspicious transaction reports as well as other information as required by national legislation such as cash transaction reports, wire transfers reports and other threshold-based declarations/disclosures. ${ }^{28}$ By the receipt of information, obtained through the receipt function, the FIU can begin the use of such information in the context of the fulfilling its central role - making the analysis of received information. ${ }^{29}$ While all information should be considered, the analysis may focus either on each single disclosure received or on appropriate selected information, depending on the type and volume of the disclosures received, and on the expected use after dissemination. During the stage consisting on making an analysis, the FIU can use analytical software to process information more efficiently and assist in establishing relevant links. However, such tools cannot fully replace the human judgement element of analysis. In this regard, it is worth mentioning that FIUs conducts usually the following two types of analysis: 1) operational analysis and 2) strategic analysis. One the one side, operational analysis means the use of available and obtainable information for the subsequent purposes: a) to identify specific targets (e.g. persons, assets, criminal networks and associations), b) to follow the trail of particular activities or transactions, and c)

\footnotetext{
$27 \quad$ Ibid., p. 108

28 Financial Intelligence Units, An Overview, International Monetary Fund, Washington, D.C, 2004, pp. $42-46$

29 Scherrer, A., Fighting tax crimes - Cooperation between Financial Intelligence Units, European Union, Brussels, 2017, pp. 19-20
} 
to determine links between those targets and possible proceeds of crime. One the other side, strategic analysis covers the use of available and obtainable information, including data that may be provided by other competent authorities for the succeeding purposes: a) to identify trends and patterns related with the crime; b) to determine threats and vulnerabilities related with the crime and c) to establish policies and goals for the FIU. Therefore, in order to conduct proper analysis, the FIU should have access to the widest possible range of financial, administrative and law enforcement information, including information from open or public sources, as well as relevant information collected and/or maintained by, or on behalf of, other authorities and, where appropriate, commercially held data. ${ }^{30}$ The last role of FIU is related to the dissemination of the information meaning that this body should be able to disseminate spontaneously or upon request information and the results of its analysis to relevant competent authorities. In connection with this, it is also noteworthy that there are two modality for the dissemination of information: 1) spontaneous dissemination and 2) dissemination upon request. The spontaneous dissemination means that the FIU should be able to disseminate information and the results of its analysis to competent authorities when there are grounds to suspect the existence of a crime, allowing the recipient authorities to focus on relevant information. On the contrary, dissemination of required information upon request means that FIU should respond to the demand of requesting authority, however, the final decision in this case whether the required information will be exchanged or not depends fully on the decision made by the FIU. ${ }^{31}$

\subsection{EXCHANGE OF INFORMATION BETWEEN COMPETENT AUTHORITIES}

Efficient cooperation between competent authorities aims at facilitating effective supervision of financial institutions. For that reason, competent authorities should exchange the financial information related to or relevant for purposes of prevention, detection and investigation of fraud and other crimes affecting financial interests. In that context, competent authorities should be able to exchange with foreign counterparts' information domestically available to them, including information held by financial institutions. ${ }^{32}$ The information relevant for purposes of prevention, detection and investigation of fraud and other crimes affecting

30 Stroligo, K.; Hsu, C.; Kouts, T., Financial Intelligence Units Working With Law Enforcement Authorities and Prosecutors, International Bank for Reconstruction and Development / The World Bank, Washington, DC, 2018, p. 12

31 FATF Recommendation Interpretive Note to Recommendation 29 (Financial Intelligence Units), See in FATF (a), note 25, pp. 97-98

32 FATF (b), Consolidated FATF Standards on Information Sharing, FATF 2016, pp. 28-29 
financial interests includes the following: a) regulatory information, such as information on the domestic regulatory system, and general information on the financial sectors; b) prudential information, such as information on the financial institution's business activities, beneficial ownership, management, and fit and properness, and c) other relevant information, such as information on internal procedures and policies of financial institutions, customer due diligence information, customer files, samples of accounts and transaction information. In order to facilitate effective group supervision competent authorities should be able to conduct inquiries on behalf of foreign counterparts, and, as appropriate, to authorize or facilitate the ability of foreign counterparts to conduct inquiries themselves in the country. However, any dissemination of exchanged information or use of that information beyond purposes originally approved, should be subject to prior authorization by the requested competent authorities, unless the requesting competent authorities is under a legal obligation to disclose or report the information. In such cases, at a minimum, the requesting financial supervisor should promptly inform the requested authority of this obligation. ${ }^{33}$

\subsection{EXCHANGE OF INFORMATION BETWEEN LAW ENFORCEMENT AUTHORITIES}

In the respect of the exchange of relevant information for purposes of prevention, detection and investigation of fraud and other crimes affecting financial interests, it should be also noted that law enforcement authorities should exchange domestically available information with foreign counterparts for intelligence or investigative purposes, including the identification and tracking of the proceeds and instrumentalities of crime. ${ }^{34}$ In order to be able to fulfill their tasks law enforcement authorities are authorized: 1) to use any investigative techniques available in accordance with their domestic law, to conduct inquiries and obtain information on behalf of foreign counterparts; 2) to govern any restrictions on use imposed by the requested law enforcement authority during law enforcement cooperation, such as the agreements between Europol and individual countries; 3 ) to form joint investigative teams to conduct cooperative investigations; 4) when necessary, to establish bilateral or multilateral arrangements to enable such joint investigations and 5) to join and support existing law enforcement networks, and develop bilateral contacts with foreign law enforcement agencies, including placing liaison officers abroad, in order to facilitate timely and effective cooperation. ${ }^{35}$

FATF (a), note 25, pp. 108-109

34 Hollywood, J.; Winkelman, Z., Improving Information-Sharing Across Law Enforcement: Why Can't We Know?, Random corporation, California, 2015, pp. 4-5

35 FATF (a), note 25, pp. 109-110 


\subsection{EXCHANGE OF INFORMATION BETWEEN NON-COUNTERPARTS}

The exchange of information does not only include the cooperation with counterparts, but also with non-counterparts. In this regard, competent authorities should be able to permit a prompt and constructive exchange of information directly or indirectly with non-counterparts, applying the general principles of cooperation abovementioned. By acting under these principles, indirect exchange of information refers to the requested information passing from the requested authority through one or more domestic or foreign authorities before being received by the requesting authority. Since this type of the exchange of information includes the existence of intermediaries, such an exchange of information and its use may be subject to the authorization of one or more competent authorities of the requested country. In addition, the competent authority that requests the information should always make it clear for what purpose and on whose behalf the request is made. ${ }^{36}$

\section{THE NEW NATIONAL FRAMEWORK IN AREA OF THE PROTECTION OF FINANCIAL SYSTEM FROM ILLEGAL ACTIVITIES AFFECTING THE FINANCIAL INTERESTS}

In the Republic of Serbia in 2017 is adopted new Law on the Prevention of Money Laundering and the Financing of Terrorism ${ }^{37}$ (hereinafter: the Law), amended in 2019. ${ }^{38}$ Bearing in mind that, this part of the paper is dedicated to the analysis of the national framework in the area of the exchange of information relevant for prevention, detection and investigation of these crimes affecting financial interests. Immediate and direct access to the relevant information for the detection of financial crimes is an indispensable source of data for successful criminal investigation as well as for the timely identification, tracing and freezing of related assets in view of their confiscation. In that sense, the new adopted EU framework represented in Directive (EU) 2019/1153 is of special importance for the strengthening of the framework of the Republic of Serbia in the context of accession and negotiations process to EU.

However, before the analysis of the special provision dedicated to different types of the exchange of information relevant for the protection of the financial system, it is worthwhile noting to analyze the definition of money laundering as well as

\footnotetext{
$36 \quad$ Ibid., p. 110

37 Law on the Prevention of Money Laundering and the Financing of Terrorism, Official Gazette of Republic of Serbia, Official Gazette of Republic of Serbia, No. 113/2017 and 91/2019

38 See more Milošević, M., Novi Zakon o sprečavanju pranja novca i finansiranja terorizma, Časopis Izbor sudske prakse, no. 3, 2018, pp. 9-13
} 
terrorist financing. ${ }^{39}$ According to Article 2 of the Law, money laundering means the following: 1) conversion or transfer of property acquired through the commission of a criminal offence; 2) concealment or misrepresentation of the true nature, source, location, movement, disposition, ownership of or rights with respect to the property acquired through the commission of a criminal offence; 3) acquisition, possession, or use of property acquired through the commission of a criminal offence. ${ }^{40}$ On the other side, terrorism financing means the providing or collecting of property, or an attempt to do so, with the intention of using it, or in the knowledge that it may be used, in full or in part: 1) in order to carry out a terrorist act; 2) by terrorists; 3) by terrorist organizations. ${ }^{41}$ In this regard, it should be noted that this definition is not fully in line with the definition of money laundering adopted in the Criminal Code of the Republic of Serbia. According to this Code, money laundering means the following acts: a) converting or transfering property originating from a criminal activity, with intent to conceal or misrepresent the unlawful origin of the property; b) concealing and misrepresenting facts on the property originating from a criminal offence; c) obtaining, keeping or using property with the knowledge, at the moment of receiving, that such property originates from a criminal offence. In other words, the Criminal Code stipulates that the property that is the subject of money laundering does not have to originate from a predicate criminal offense, but prescribes that property that is the subject of money laundering should originate from a criminal activity. By adopting this solution the scope of its application has been extended meaning that a previous (predicate) offense does not have to be individually determined in the given case, enabling criminal prosecution for this crime without a prior conviction for a predicate criminal offense. Therefore, it is sufficient for criminal prosecution for this crime to establish that the money or property was acquired through criminal activity. ${ }^{42}$

Moreover, it should be noted that the framework of the Republic of Serbia regarding the rules referred to in the Criminal Code is harmonized with the relevant EU framework. Precisely, the meaning of money laundering prescribed in Criminal Law is in compliance with the solutions referred to in Directive (EU) 2015/849 of the European Parliament and of the Council of 20 May 2015 on the prevention of the use of the financial system for the purposes of money laundering or terrorist financing as well as Directive (EU) 2018/843 of the European Parliament and of

\footnotetext{
39 Sinanović, B., Pranje novca, Bilten sudske prakse Vrhovnog suda Srbije, no. 2, 2011, pp. 61-68

40 See more in Važić, N. Pranje Novca-Materijalni I Procesni Aspektu Medunarodnom I Domaćem Zakonodavstvu, Bilten sudske prakse Vrhovnog suda Srbije, no. 2, 2008, pp. 114-141

${ }^{41}$ Lukić T., Borba Protiv Pranja Novca I Finansiranja Terorizma U Republici Srbiji, Zbornik radova Pravnog fakulteta u Novom Sadu, no. 2, 2010, p. 203

42 Criminal Code of Republic of Serbia, Official Gazette of Republic of Serbia, No. 85/2005, 88/2005, $107 / 2005,72 / 2009,111 / 2009,121 / 2012,104 / 2013,108 / 2014,94 / 2016$ and 35/2019
} 
the Council of 30 May 2018 amending Directive (EU) 2015/849 on the prevention of the use of the financial system for the purposes of money laundering or terrorist financing. ${ }^{43}$

In the context of harmonization with the abovementioned solutions Law on seizure and confiscation of the proceeds from crime was adopted in 2013. By adopting this Law the possibility for international cooperation and the exchange of information was extended including the group of criminal offenses against financial interests. In this sense, of special importance are those rules related to the organisation and jurisdiction of the Financial Intelligence Unit. This unit processes received and sent requests obtained through channels of international exchange of information, in order to detect property arising from a criminal offense and to confiscate it temporary or permanent. Furthermore, regarding the issue of competent authorities authorised for the confiscation or seizure of assets of money laundering it should be mentioned that in the Republic of Serbia these tasks perform The Directorate for Management of Seized and Confiscated Assets under Ministry of Justice. The Directorate manages the seized or confiscated proceeds from crime, objects resulting from the commission of a criminal offence and material gain obtained by a criminal offence. Also, this authority conducts professional assessment of the seized proceeds from crime, sells provisionally the seized proceeds from crime, administers funds thus obtained, and performs other tasks in accordance with this Law. ${ }^{44}$

When it comes to the regulation of corruption it should be mentioned that in the Republic of Serbia Law on the Organisation and Jurisdiction of Government Authorities on the Suppression of Organised Crime, Terrorism and Corruption was adopted in 2016 prescribing the list of criminal offenses against official duty under the regime of this Law. In the context of the exchange of the information applied to these offences, it is worthwhile noting that this Law has introduced several new bodies in the struggle against corruption such as: 1) Task Forces; 2) Financial Forensic Divisions; 3) Connecting Officials. Task Forces are special organisational structures within each Public Prosecutor's office with the aim to deal with the process of prosecuting complex cases within its jurisdiction. Furthermore, Financial Forensic Divisions are composed of state officers who shall be re-

43 Directive (EU) 2015/849 of the European Parliament and of the Council of 20 May 2015 on the prevention of the use of the financial system for the purposes of money laundering or terrorist financing, Official Journal of the European Union, L 141/73 of 5 June 2015; Directive (EU) 2018/843 of the European Parliament and of the Council of 30 May 2018 amending Directive (EU) 2015/849 on the prevention of the use of the financial system for the purposes of money laundering or terrorist financing, Official Journal of the European Union, L 156/43 of 19 June 2018

44 Law on seizure and confiscation of the proceeds from crime Official Gazette of Republic of Serbia, No. $32 / 2013,94 / 2016$ and 35/2019 
sponsible to analyse financial data and assist public prosecutors to decide whether there are sufficient grounds to launch criminal proceedings. The term connecting officials means government officials employed in some governmental bodies such as e.g. Customs Office, National Bank of Serbia etc. who shall be responsible to keep communication with public prosecutors and to provide them with necessary information. ${ }^{45}$

As the recognition of these achievements, Committee of Experts on the Evaluation of Anti-Money Laundering Measures and the Financing of Terrorism (hereinafter: Moneyval) in its last report in 2019 regarding the position of Republic of Serbia has noticed significant progress in strengthening the framework for combating money laundering and terrorist financing, meaning that there are no areas in which Serbia would be assessed as non-compliant. In the forthcoming period, according to Moneyval Serbia should report on further progress in strengthening the implementation of adopted measures against money laundering and terrorist financing. ${ }^{46}$

Finally, it should be added that although in the framework of the Republic of Serbia there is still no regulation concerning criminal law protection against criminal offences affecting EU financial interest, there is the national anti-fraud strategy to protect the EU's financial interests for the period from 2017 to $2020 .{ }^{47}$ In the context of the exchange of relevant information it is worthwhile mentioning that the special anti-fraud coordination service (known as: AFCOS) under the Ministry of Finance was established with the aim to cooperate with the European Commission during investigations and to report to the Commission on irregularities and suspected fraud cases. ${ }^{48}$

\subsection{TYPES OF THE EXCHANGE OF INFORMATION RELEVANT FOR THE PROTECTION OF THE FINANCIAL SYSTEM}

When it comes to the issue of the exchange of information relevant for the protection of the financial system against criminal offences targeting financial interests,

45 Law on the Organisation and Jurisdiction of Government Authorities on the Suppression of Organised Crime, Terrorism and Corruption Official Gazette of Republic of Serbia, No. 94/2016 and 87/2018

46 Committee of Experts on the Evaluation of Anti-Money Laundering Measures and the Financing of Terrorism Anti-money laundering and counter-terrorist financing measures, Serbia, 3rdEnhanced Follow-up Report December 2019

47 National anti-fraud strategy to protect the EU's financial interests from the period 2017-2020, Official Gazette of Republic of Serbia, No. 98/2017

48 European Commission, Commission Staff Working Document Serbia 2019 Report, European Commission, Brussels, 2019 p. 95 
it should be noted that the Law recognizes six types of the exchange applicable to specific forms of internal as well as international cooperation including the following: 1) requesting data from the obliged entities (Article 73); 2) requesting data from the competent state authorities and holders of public authority (Article 74); 3) requesting data from the law enforcement authority (Article 77); 4) dissemination of data to competent authorities (Article 78); 5) requesting data from foreign countries (Article 80); 6) dissemination of data to competent state authorities of foreign countries (Article 81). Moreover, it should be pointed out that in accordance with Article 72 of the Law like the law enforcement authority the Administration for the Prevention of Money Laundering (hereinafter: the Administration) is established, as an administrative authority under the Ministry competent for finance. Among other duties, the Administration has authorized to collect, process, analyze and disseminate to the competent authorities obtained information, data and documentation.

In the context of requesting data from the obliged entities, such as banks and other financial institutions, it is noteworthy that the Administration may submit the request if only there are reasons to reasonable grounds for the suspect a crime affecting financial interests. If the Administration finds that there are reasons to suspect criminal offences targeting financial interests in respect to certain transactions or persons, it may pursuant to Article 76 of the Law issue a written order to the obliged entity to monitor all transactions or business operations of such persons that are conducted in the obliged entity. The obliged entity is required to inform the Administration of each transaction or business operation within the deadlines specified in the order. Unless otherwise provided in the order, the obliged entity is required to report each transaction or business operation to the APML before a transaction or a business activity is conducted, as well as to indicate in the notification the deadline for the transaction or business operation to be completed. If due to the nature of a transaction or a business operation or for other justified reasons the obliged entity cannot act within the deadlines specified in the order it is required to inform the Administration of the transaction or operation right after they are conducted, and the following working day at the latest, providing reasons in the notification as to why it did not act in line with the order. The measure of monitoring of customer's financial activities shall last for three months from the day when the order was issued, and may be extended by one month at a time, but for no more than six months following the day the order was issued.

Anyway, under these conditions, as reported by Article 73 of the Law, the Administration may request from the obliged entity the following type of information:1) data from the customer and transaction records kept by the obliged entity; 2) information about the customer's money and assets held with the obliged entity; 
3) data on turnover of customer's money or assets by the obliged entity; 4) data on other business relations of a customer established by the obliged entity; 5) other data and information necessary for detecting or proving the crime concerning a persons to whom there are reasons to suspect committing a crime affecting financial interests. In respect of this type of the exchange of information, the special significance has the provision on the deadline for the respond of obliged entities to the request of the Administration. In that context, it should be noted that in accordance with the Law it is prescribed both options, including setting shorter and longer deadlines, different from the deadline which was initially determined. Therefore, the general rules is that the obliged entity is required to provide the Administration with required data, information and documentation without delay but no later than eight days following the reception of the request. However, if it is necessary for deciding in urgent cases the Administration may set in its request a shorter deadline for providing data, information and documentation. Reversely, only due to the size of documentation or for other justified reasons, the Administration may set a longer deadline for providing documentation, or inspect the documentation on the obliged entity's premises.

Furthermore, in order to assess whether there are reasons to suspect criminal offences targeting financial interests in relation to certain transactions or persons, in line with Article 74 of the Law the Administration may request data, information and documentation necessary for detecting and proving these crimes, from the state authorities, organizations and legal persons entrusted with public authorities. These authorities and organizations are required to provide the Administration in writing form with requested data, within eight days following the receipt of the request. In the case of this type of the exchange of information is not stipulated the possibility for the extension of deadline, but only the shortening of deadline. In this sense, the Administration may request, in urgent cases, the receipt of required data within the deadline shorter than eight days.

In the respect of the exchange of information from the law enforcement authority, it is important to stress that, in consonance with Article 77 of the Law, if there are reasons for suspicion in respect of certain transactions concerning criminal offences targeting financial interests the state authority such as court, public prosecutor and police may, in a written and justified form, request from the Administration data and information necessary for proving these criminal offences. Therefore, it should be underlined that the Administration shall refuse the request if they do not justify the reasons of suspicion of criminal offences targeting financial interests, as well as in cases when it is obvious that such reasons do not exist, by informing the initiator in writing of the reasons why it refused the request. Moreover, as stated in Article 78, in order to be able competent state authorities to undertake 
measures within their competence it is prescribed the possibility which covers situation of dissemination of data to competent authorities, which is applicable in cases where the Administration finds, based on the obtained data, information and documentation, that there are reasons to suspect criminal offences targeting financial interests in relation to a transaction or person.

Ultimately, the last two types of the exchange of relevant information are related to the international cooperation. One the one hand, the Law deals with the request of data from foreign countries. Thus, in the sense of Article 80, it should be noticed that the Administration is authorized to request data, information and documentation necessary for the prevention and detection of criminal offences targeting financial interests from the competent authorities of foreign countries. However, it is determined that the Administration may use obtained data, information and documentation only for the purposes for which they are sought. If there is a need to send requested and obtained data to another state authority, the Administration shall demand prior consent of the state authority of the foreign country which provided that data. This provision is justified since it should be cleared that the Administration may not use obtained data, information and documentation contrary to the conditions and restrictions determined by the state authority of the foreign country that provided that data. Reversely, in line with Article 81 it is determined situation of the dissemination of data to the competent state authorities of foreign countries. In that context, it is worthwhile noting that the Administration may disseminate data, information and documentation in respect to transactions or persons for whom there are reasons to suspect criminal offences targeting financial interests to the state authorities of foreign countries competent for the prevention and detection of these crime either at their written and justified request, or at its own initiative. However, it should be cleared that the Administration may reject the request if the dissemination of such data would compromise or could compromise the course of a criminal procedure in the Republic of Serbia, by informing in writing the state authority of the foreign country about the reasons for rejection. Finally, in the case of approval of dissemination of information, the Administration may set conditions and restrictions under which an authority of a foreign country is allowed to use requested data, information and documentation and further dissemination of information to any other authority of a foreign country may not be made without a prior consent of the Administration.

\section{CONCLUSION}

There has been a significant legislative action at the recent times at the EU level in the area of the protection of financial interests. By adopting Directive (EU) 
2017/1371, the EU framework was enriched with the list of criminal offenses targeting and affecting EU financial interests. In this way, at EU level not only was prescribed various number of fraud scheme, but also other financial crimes, including money laundering, passive as well as active corruption, and misappropriation. However, regulation of substantive matters of significance for the prevention, detection and investigation of financial crimes was represented only required but not the sufficient step for combating this type of criminal activities. In other words, in the respect of proper and efficient fight against financial crimes there was a lack of legal possibilities for national and European authorities to access to relevant financial information as well as the lack of cooperation between them. What is meant here is that the adequate procedural rules for effective combating of this types of crime had not yet been adopted. On these grounds, by adopting of the Directive (EU) 2019/1153 laying down rules facilitating the use of financial and other information for the prevention, detection, investigation or prosecution of certain criminal offences in 2019, has approved a strong and coordinated response in the area of the protection of EU financial interests. Namely, this legal act has created new possibilities for the access by competent authorities to financial and other information and has established the special rules in the respect of the conditions for the exchange of information between competent authorities and financial intelligence units as well as between financial intelligence units and Europol. However, although in the recent period there have been significant improvements in the EU framework on the protection of the financial interests against financial crimes there is still a lack of effective implementation of adopted standards, in particular in the area of the exchange of relevant information in timely manner. Therefore, in order to be prepared for all applicable and new methods and techniques used by criminals and organized crime groups, it is extremely important that authorities constantly collect and exchange requested data regarding financial crimes. Precisely, the risk of the new threats in the area of the abuse of the financial system through fraud and other financial crimes requires application of the multinational approach in order to combat this phenomenon effectively, since it is unrealistic to expect that one or several countries, without others, will achieve any significant results in the respect of prevention, detection and investigation at the international level. Therefore, owing to the fact that the abuse of the financial system through financial crimes as a phenomenon cannot be fully eradicated, it seems compulsory to take into consideration significant improvements achieved in this area at international level. Hence, it should be aware that by working together the whole international community can achieve much more in the context of controlling this phenomenon. 
To conclude, concerning the protection of financial interests, the EU framework is in compliance with existing international standards, introducing several remarkable provisions. The only thing that remains is the need for its proper implementation. In that regard, there are a few significant recommendations for the acceleration of the implementation of adopted measures on combating financial crimes. In the area of early detection of these crimes, the investigative focus should be on the recognition and analysis of indicators for identifying suspected transactions. The next recommendation for the adequate implementation of adopted measures on preventing financial crimes implies timely reporting and exchanging information of suspected transactions. Finally, the comprehensive response to the prevention of financial crimes includes as broad as possible cooperation between authorities including mutual support among national financial units, between the competent authorities and legal enforcement authorities or other authorities as well. Ultimately, following accomplished achievements at the EU level, the Republic of Serbia has undertaken appropriate legislative steps by adopting new framework, including the provisions on the exchange of information between relevant authorities for the purposes of prevention, detection and investigation of the crimes affecting financial interests. Therefore, when it comes to the Serbian Law, it can be noticed that national legislation is in compliance with the adopted EU framework and international standards in this area. In addition, in the respect of the exchange of relevant financial and other information, it seems that it provides broader possibilities for the effective internal and international cooperation.

\section{REFERENCES}

\section{BOOKS AND ARTICLES}

1. Borlini L.; Montanaro, F., The Evolution Of The Eu Law Against Criminal Finance: The "Hardening" of FATF Standards Within The EU, George Town Journal Of International Law, vol. 48, 2017, pp. 1009-1062

2. Finn, H., The fifth anti-money laundering and terrorist financing directive (AML 5)-Key aspects and changes Arendt \& Medernach, Luxembourg, 2018

3. Fletzberger, B., 5th Anti-Money Laundering Directive - a summary of the main points, PayTechLaw, 2018

4. Hollywood, J.; Winkelman, Z., Improving Information-Sharing Across Law Enforcement: Why Can't We Know?, Random corporation, California, 2015, pp. 1-32.

5. Kostić, J., Krivičnopravna zaštita finansijskih interesa Evropske unije, Institut za uporedno pravo, Beograd, 2018

6. Lukić T., Borba Protiv Pranja Novca I Finansiranja Terorizma U Republici Srbiji, Zbornik radova Pravnog fakulteta u Novom Sadu, no. 2, 2010, pp. 197-215. 
7. Maesa, C., Directive (EU) 2017/1371 on the Fight Against Fraud to the Union's Financial Interests by Means of Criminal Law: A Missed Goal?, European papers: a journal on law and integration, vol. 3, no. 3, 2018, pp. 1455-1469.

8. Mathis, A., Combating Fraud and Protecting the EU's Financial Interests, European Parliament, Brussels, 2020, pp. 1-6.

9. Milošević, M., Novi Zakon o sprečavanju pranja novca i finansiranja terorizma, Časopis "Izbor sudske prakse", no. 3, 2018, pp. 9-13.

10. Nunzi, A., Exchange of Information and Intelligence among Law Enforcement Authorities a European Union Perspective, Revue internationale de droit penal, vol. 78, no. 1-2, 2007, pp. $143-151$

11. Paunović, N., Terrorist Financing As The Associated Predicate Offence Of Money Laundering In The Context Of The New Eu Criminal Law Framework For The Protection Of The Financial System, in: Duić, D.; Petrašević, T.; Novokmet, A. (eds), EU and Member States - Legal and Economic Issues, Faculty of Law, Josip Juraj Strossmayer University of Osijek, Osijek, 2019, pp. 659-683

12. Picard, M, Financial Crimes: The constant challenge of seeking effective prevention solutions, Journal of Financial Crime, vol.15, no. 4, 2008, pp. 383-397

13. Quintel, T., Follow the Money, if you can Possible solutions for enhanced FIU cooperation under improved data protection rules, Law Working Paper Series Paper, vol. 1, 2019, pp. 1-12

14. Sánchez D., (a) The Directive on the Fight against Fraud to the Union's Financial Interests and its Transposition into the Spanish Law, Perspectives on Federalism, vol. 11, no. 3, 2019, p.123-154

15. Sánchez, D., (b), The European Union Criminal Policy against Corruption: Two Decades of Efforts, Politica Criminal, vol. 14, no. 27, 2019, pp. 520-548

16. Scherrer, A., Fighting tax crimes - Cooperation between Financial Intelligence Units, European Union, Brussels, 2017, pp. 1-80

17. Schott, P., Reference Guide to Anti-Money Laundering and Combating the Financing of Terrorism, The World Bank and The International Monetary Fund, Washington DC, 2006

18. Sinanović, B., Pranje novca, Bilten sudske prakse Vrhovnog suda Srbije, no. 2, 2011, pp.61-68

19. Stroligo, K.; Hsu, C.; Kouts, T., Financial Intelligence Units Working With Law Enforcement Authorities and Prosecutors, International Bank for Reconstruction and Development / The World Bank, Washington, DC, 2018, pp. 1-82

20. Šuput, J., Harmonizacija nacionalnog zakonodavstva Republike Srbije sa Konvencijom o zaštiti finansijskih interesa Evropske unije, Evropsko zakonodavstvo, vol.13, no. 47/48, 2014, pp.187-202.

21. Tomić S., New EU Directive On The Prevention Of The Use Of The Financial System For The Purposes Of Money Laundering And Terrorist Financing, Bankarstvo, vol. 47, no.2, 2018, pp. 108-113

22. Tudor, G., Criminalizing fraud affecting the European Union's financial interests by diminution of VAT resources, Juridical Tribune, vol. 9, no. 1, 2019, pp. 137-146

23. Važić, N. Pranje Novca-Materijalni I Procesni Aspektu Mectunarodnom I Domaćem Zakonodavstvu, Bilten sudske prakse Vrhovnog suda Srbije, no. 2, 2008, pp. 114-141 


\section{EU LAW}

1. Directive (EU) $2015 / 849$ of the European Parliament and of the Council of 20 May 2015 on the prevention of the use of the financial system for the purposes of money laundering or terrorist financing, Official Journal of the European Union, L 141/73 of 05 June 2015

2. Directive (EU) $2016 / 680$ of the European Parliament and of the Council of 27 April 2016 on the protection of natural persons with regard to the processing of personal data by competent authorities for the purposes of the prevention, investigation, detection or prosecution of criminal offences or the execution of criminal penalties, and on the free movement of such data, Official Journal of the European Union, L 119/89 of 04 May 2016

3. Directive (EU) 2017/1371 of the European Parliament and of the Council of 5 July 2017 on the fight against fraud to the Union's financial interests by means of criminal law, Official Journal of the European Union, L 198/29 of 28 July 2017

4. Directive (EU) 2018/843 of the European Parliament and of the Council of 30 May 2018 amending Directive (EU) 2015/849 on the prevention of the use of the financial system for the purposes of money laundering or terrorist financing, Official Journal of the European Union, L 156/43 of 19 June 2018

5. Directive (EU) 2019/1153 of the European Parliament and of the Council of 20 June 2019 laying down rules facilitating the use of financial and other information for the prevention, detection, investigation or prosecution of certain criminal offences, Official Journal of the European Union, L 186/122 of 11 July 2019

6. European Commission, Commission Staff Working Document Serbia 2019 Report, European Commission, Brussels, 2019

\section{INTERNATIONAL LAW}

1. FATF (a) (2012-2019), International Standards on Combating Money Laundering and the Financing of Terrorism \& Proliferation, FATF, Paris, 2019

2. FATF (b), Consolidated FATF Standards on Information Sharing, FATF 2016

3. Financial Intelligence Units: An Overview, International Monetary Fund, Washington, D.C, 2004

4. OECD, Improving Co-operation between Tax Authorities and Anti-Corruption Authorities in Combating Tax Crime and Corruption, OECD, Paris, 2018

\section{LIST OF NATIONAL REGULATIONS AND ACTS}

1. Committee of Experts on the Evaluation of Anti-Money Laundering Measures and the Financing of Terrorism Anti-money laundering and counter-terrorist financing measures, Serbia, 3rdEnhanced Follow-up Report December 2019

2. Criminal Code of Republic of Serbia, Official Gazette of Republic of Serbia, No. 85/2005, $88 / 2005,107 / 2005,72 / 2009,111 / 2009,121 / 2012,104 / 2013,108 / 2014,94 / 2016$ and $35 / 2019$

3. Law on seizure and confiscation of the proceeds from crime, Official Gazette of Republic of Serbia, No. 32/2013, 94/2016 and 35/2019 
4. Law on the Organisation and Jurisdiction of Government Authorities on the Suppression of Organised Crime, Terrorism and Corruption Official Gazette of Republic of Serbia, No. $94 / 2016$ and $87 / 2018$

5. Law on the Prevention of Money Laundering and the Financing of Terrorism, Official Gazette of Republic of Serbia, Official Gazette of Republic of Serbia, No. 113/2017 and $91 / 2019$

6. National anti-fraud strategy to protect the EU's financial interests from the period 20172020, Official Gazette of Republic of Serbia, No. 98/2017

\section{WEBSITE REFERENCES}

1. [https://ec.europa.eu/info/sites/info/files/file_import/european-semester_thematic-factsheet_fight-against-corruption_en_0.pdf], p. 2, accessed 15. April 2020

2. EU directive gives greater access to financial information, [https://www.taxjournal.com/articles/eu-directive-gives-greater-access-to-financial-information], accessed on 15. April 2020

3. Fight Against Corruption,

4. Juszczak, A.; Sason, E., The Directive on the Fight against Fraud to the Union's Financial Interests by means of Criminal Law (PFI Directive), [https://eucrim.eu/articles/the-pfi-directivefight-against-fraud/], accessed on 15. April 2020

5. Wahl, T., Commission: Need for Reinforced FIU Cooperation, [https://eucrim.eu/news/commission-need-reinforced-fiu-cooperation/], accessed on 15. April 2020

6. Wahl, T., Law Enforcement Access to Financial Information, [https://eucrim.eu/news/new-directive-law-enforcement-access-financial-information/], accessed on 15. April 2020 